\title{
Cellular ionic effects of insulin in normal human erythrocytes: a nuclear magnetic resonance study
}

\author{
M. Barbagallo ${ }^{1}$, R.K. Gupta ${ }^{2}$ and L.M. Resnick ${ }^{1}$ \\ ${ }^{1}$ Cardiovascular Center, New York Hospital-Cornell Medical Center, New York, \\ and ${ }^{2}$ Department of Physiology and Biophysics, Albert Einstein College of Medicine, Bronx, New York, USA
}

\begin{abstract}
Summary. Elevated erythrocyte cytosolic free calcium, and suppressed free magnesium and $\mathrm{pH}$ values are associated with the hyperinsulinaemia and insulin resistance of hypertension, obesity, and Type 2 (non-insulin-dependent) diabetes mellitus. To determine the role of insulin in this process, we utilized ${ }^{19} \mathrm{~F}$ - and ${ }^{31} \mathrm{P}$-nuclear magnetic resonance spectroscopy to study the cellular ionic effects of insulin in vitro on normal human erythrocytes. Insulin elevated cytosolic free calcium levels in a dose- and time-dependent manner. The effect began at $10 \mu \mathrm{U} / \mathrm{ml}$, peaked at $200 \mu \mathrm{U} / \mathrm{ml}$, and continued at both the $500 \mu \mathrm{U} / \mathrm{ml}$ and $1000 \mu \mathrm{U} / \mathrm{ml}$ doses. At $200 \mu \mathrm{U} / \mathrm{ml}$, free calcium levels rose from $24.6 \pm 2.5 \mathrm{nmol} / 1$ to a peak value at $120 \mathrm{~min}$ of $66.4 \pm 11 \mathrm{nmol} / 1$ ( $p<0.05 \mathrm{vs} \mathrm{basal}$ ), levels remaining elevated throughout the incubation $(45.7 \pm 5.6$ $\mathrm{nmol} / 1$ at $60 \mathrm{~min}$, and $47.9 \pm 9.1 \mathrm{nmol} / 1$ at $180 \mathrm{~min}, p<0.05 \mathrm{vs}$
\end{abstract}

basal, respectively). Similarly, insulin also increased intracellular free magnesium at all time points (basal: $177 \pm$ $11 \mu \mathrm{mol} / \mathrm{l} ; 60 \mathrm{~min}: 209 \pm 19 \mu \mathrm{mol} / \mathrm{l} ; 120 \mathrm{~min}: 206 \pm 22 \mu \mathrm{mol} / \mathrm{l}$; and $180 \mathrm{~min}: 202 \pm 12 \mu \mathrm{mol} / \mathrm{l} ; p<0.05$ vs basal at all times). No insulin-induced changes in $\mathrm{pH}$ were observed. We conclude (i) that insulin in physiological concentrations may participate in regulating divalent cations in the mature human erythrocyte, (ii) that insulin per se cannot account for the previously described cellular ionic lesions of hypertension and diabetes, and (iii) that future clinical studies of cell ion metabolism should be conducted in the fasting state, be controlled for ambient circulating insulin levels, or both.

Key words: Insulin, calcium, magnesium, $\mathrm{pH}$, nuclear magnetic resonance spectroscopy, erythrocytes.
Hyperinsulinaemia and peripheral insulin resistance are associated with both essential hypertension and coronary heart disease [1-3], and numerous observations support the suggestion that insulin may directly contribute to the pathophysiology of these syndromes [4-8].

We have studied the relationship between insulin and hypertensive cardiovascular disease at the cellular ionic level, and have found intracellular ionic abnormalities in erythrocytes of subjects with hypertension, obesity, and Type 2 (non-insulin-dependent) diabetes mellitus, including higher cytosolic free calcium and reciprocally lower free magnesium levels [9]. Furthermore, these abnormalities were closely related to the increase in the blood pressure [10], to the degree of cardiac hypertrophy [11], and to the hyperinsulinaemia and insulin resistance of hypertension [12].

Thus, to determine the extent to which insulin itself might be responsible for these cellular ionic abnormalities, we utilized ${ }^{31} \mathrm{P}$ - and ${ }^{19} \mathrm{~F}$-nuclear magnetic resonance (NMR) spectroscopy to measure the effects of graded doses of insulin in vitro on normal erythrocytes. Our results document direct effects of insulin on ion levels in human erythrocytes, resulting in the cellular accumulation of both free calcium and free magnesium. We suggest that these ionic effects, if also reflective of insulin action elsewhere, may underlie at least some of the tissue actions attributable to insulin [13].

\section{Subjects and methods}

After an overnight fast $50 \mathrm{ml}$ of heparinized blood was drawn between 09.00-12.00 hours from non-diabetic normotensive otherwise healthy volunteers who were not taking any medication at the Cardiovascular Center of the New York Hospital-Cornell Medical Center. Blood for each sample $(n=10$ for each study) was processed using multiple washings in isotonic Hanks' buffered salt solution (HBSS), pH 7.4, and subsequently utilizing ${ }^{31} \mathrm{P}$ - and ${ }^{19} \mathrm{~F}-\mathrm{NMR}$ techniques as described below, for analysis of intracellular cations $\mathrm{Ca}_{i}$, $\mathrm{Mg}_{\mathrm{i}}$ and $\mathrm{pH}_{\mathrm{i}}$ levels before (basal $=0 \mathrm{~min}$ ) and $60,120,180$ min after the addition of regular human insulin to isolated cells $(200 \mu \mathrm{U} / \mathrm{ml})$. Incubation occurred at $37^{\circ} \mathrm{C}$ in the continuous presence of insulin.

The dose of $200 \mu \mathrm{U} / \mathrm{ml}$ was chosen after performing a dose-response curve experiment which showed that at this concentration the maximum cellular effect is reached. For this experiment increasing doses of insulin were added to separate tubes ( $n=6$ for each con- 


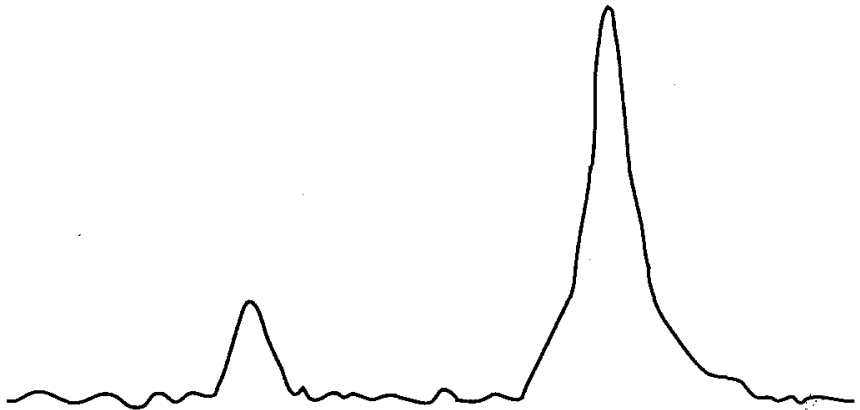

Fig.1. ${ }^{19} \mathrm{~F}$-nuclear magnetic resonance spectrum of QUIN-MF (right, second peak) and Ca-Quin-MF (left, first peak) in intact erythrocytes. Integration of the areas under the respective resonance peaks allows for a calculation of intracellular free calcium (see Subjects and Methods)

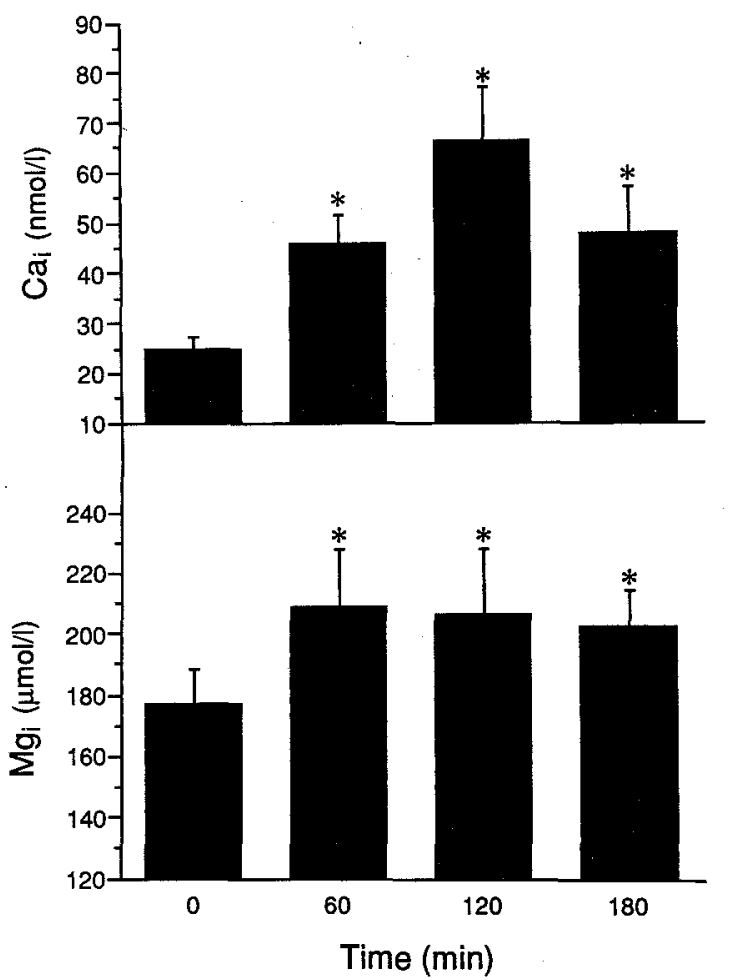

Fig. 2. Time course of the effect of insulin $(200 \mu \mathrm{U} / \mathrm{ml})$ on erythrocyte intracellular free calcium, $\mathrm{Ca}_{\mathrm{i}}$ and free magnesium, $\mathrm{Mg}_{\mathrm{i}}$ levels

centration), to achieve a final concentration range of 0 (basal, no insulin added), $10,50,100,200,500$ and $1000 \mu \mathrm{U} / \mathrm{ml}$. After $60 \mathrm{~min}$ of incubation at each concentration, ${ }^{19} \mathrm{~F}$-NMR analyses of cytosolic free calcium were repeated, and compared to the unsupplemented basal values. Our previous experience with the NMR measurements and those reported here demonstrated the stability of the basal values for the entire time course of the experiments.

\section{${ }^{31} P-N M R$ analysis of $M g_{\mathrm{i}}$ and $p H_{\mathrm{i}}$}

The methods for ${ }^{31} \mathrm{P}-\mathrm{NMR}$ analysis of $\mathrm{Mg}_{\mathrm{i}}$ and $\mathrm{pH}_{\mathrm{i}}$ have been described in detail elsewhere $[10,14]$. The intracellular magnesium concentration was determined according to the equation [10]:

$\mathrm{Mg}_{\mathrm{i}}=\mathrm{K}_{\mathrm{d}(\text { MgATP) }} \times\left(\Phi^{-1}-1\right)$

where $\mathrm{K}_{\mathrm{d}(\mathrm{MgATP})}$ is the apparent dissociation constant for the reaction $\mathrm{MgATP}=\mathrm{Mg}^{2+}+\mathrm{ATP}=0.4 \times 10^{-5} \mathrm{~mol} / \mathrm{l}$ under physiological condi- tions at $37^{\circ} \mathrm{C}$ and at $\mathrm{pH} 7.2$; and $\Phi=(\mathrm{ATP})_{\text {free }} /(\mathrm{ATP})_{\text {total }}$ is determined from the chemical shift difference of the $\alpha$ - and $\beta$-phosphoryl group resonances of ATP in the ${ }^{31} \mathrm{P}-\mathrm{NMR}$ spectrum.

The $\mathrm{pH}$ was determined by measuring the chemical shift difference of the 3 and 2 phosphoryl resonances of the 2,3 diphosphoglycerate (2,3 DPG) on the ${ }^{31} \mathrm{P}$ spectra [15]. ${ }^{31} \mathrm{P}-\mathrm{NMR}$ and the chemical shift difference of the 3- and 2-phosphoryl resonances of 2,3-diphosphoglycerate were plotted against the $\mathrm{pH}$ value at which the spectrum was obtained. A titration curve, prepared by analysing spectra obtained at various known $\mathrm{pH}$ values, was linear within the $\mathrm{pH}$ range tested and was used to determine the $\mathrm{pH}$ of unknowns [14].

\section{${ }^{19} \mathrm{~F}-\mathrm{NMR}$ analysis of $\mathrm{Ca} \mathrm{a}_{\mathrm{i}}$}

$\mathrm{Ca}_{\mathrm{i}}$ was determined in erythrocytes by a modification of the method of Levy et al. [16], using the fluorinated, membrane-permeant calcium chelator Quin-MF-AM. Blood $(10 \mathrm{ml})$ was centrifuged at $2000 \mathrm{rev} / \mathrm{min}$ for $10 \mathrm{~min}$ to separate plasma from the packed cells. The packed erythrocytes were suspended in $100 \mathrm{ml}$ of HBSS with $0.35 \mathrm{~g} \mathrm{NaHCO}_{3}$ at a $\mathrm{pH}$ of 7.4. Cells were loaded in a shaking water bath with $20 \mu \mathrm{mol} / 1$ Quin-MF-AM, a membrane permeant $\mathrm{Ca}^{2+}$ chelator, for $25 \mathrm{~min}$ at $37^{\circ} \mathrm{C}$.

Loaded cells were subsequently centrifuged at $2000 \mathrm{rev} / \mathrm{min}$ for $10 \mathrm{~min}$, the medium was aspirated, and the cells resuspended in $50 \mathrm{ml}$ of fresh HBSS together with the subject's plasma (approximately $5 \mathrm{ml}$ ) which was then incubated at $37^{\circ} \mathrm{C}$ for $90 \mathrm{~min}$. Cells were centrifuged, washed again with fresh HBSS together with another aliquot of $5 \mathrm{ml}$ of plasma, and then recentrifuged and decanted into $10 \mathrm{~mm}$ NMR tubes for analysis. ${ }^{19} \mathrm{~F}-\mathrm{NMR}$ were run on Varian VXR$500 \mathrm{NMR}$ spectometer operating at $470 \mathrm{MHz}$ and $37^{\circ} \mathrm{C}$. Free cytosolic calcium was calculated according to the formula:

$\mathrm{Ca}_{\mathrm{i}}=\mathrm{K}_{\mathrm{d} \text {,app }} \times(\mathrm{Ca}-$ Quin-MF/(Quin-MF) [9],

where $\mathrm{K}_{\mathrm{d} \text {,app }}$ of Ca-Quin-MF was calculated as $139 \mathrm{nmol} / \mathrm{l}$ in erythrocyte haemolysates at $37^{\circ} \mathrm{C}$, and where $\mathrm{Ca}-\mathrm{Quin}-\mathrm{MF} /(\mathrm{Quin}-\mathrm{MF}$ ) was calculated from the ratio of areas of the Quin-MF vs Ca-Quin-MF resonances peaks on the ${ }^{19}$ F-NMR spectrum (Fig. 1).

\section{Statistical analysis}

Data for the responses of each cellular ion species to insulin were analysed for statistical significance using one-way analysis of variance and subsequent post-hoc $t$-test (Bonferroni Dunn) (SuperAnova, Abacus Concepts Inc., Berkeley Calif., USA) for the effects of insulin over time at $0,60,120$, and $180 \mathrm{~min}$, and over the range of concentrations tested at $10,50,100,200,500,1000 \mu \mathrm{U} / 1$. All values are reported as the means $\pm S E M$.

\section{Results}

Compared to basal, unstimulated levels of intracellular free calcium $\left(\mathrm{Ca}_{1} 24.6 \pm 2.5 \mathrm{nmol} / \mathrm{l}\right)$, intracellular free magnesium $\left(\mathrm{Mg}_{\mathrm{i}}, 177 \pm 11 \mu \mathrm{mol} / \mathrm{l}\right)$, and intracellular $\mathrm{pH}$ $\left(\mathrm{pH}_{\mathrm{i}}, 7.26 \pm 0.02\right)$, insulin $(200 \mu \mathrm{U} / \mathrm{ml})$ elevated $\mathrm{Ca}_{\mathrm{i}}$ at $60 \mathrm{~min}(45.7 \pm 5.6 \mathrm{nmol} / 1, p<0.05$ vs basal $), 120 \mathrm{~min}$ $(66.4 \pm 11.0 \mathrm{nmol} / 1, p<0.05 \mathrm{vs}$ basal $)$, and $180 \mathrm{~min}(47.9 \pm$ $9.1 \mathrm{nmol} / 1, p<0.05$ vs basal) (Fig. 2). Similarly, $\mathrm{Mg}_{\mathrm{i}}$ rose in response to insulin in all subjects. This effect peaked at $60 \mathrm{~min}$ of incubation ( $209 \pm 19 \mu \mathrm{mol} / \mathrm{l}, p<0.05 \mathrm{vs}$ basal), but persisted at $120(206 \pm 22 \mu \mathrm{mol} / \mathrm{l}, p<0.05 \mathrm{vs}$ basal $)$ and $180 \mathrm{~min}$ (202 $\pm 12 \mu \mathrm{mol} / 1, p<0.05 \mathrm{vs}$ basal) (Fig. 2). No significant effect of insulin on $\mathrm{pH}_{\mathrm{i}}$ levels was detected in this in vitro erythrocyte system. After 60,120 , and $180 \mathrm{~min}$ of incubation, $\mathrm{pH}_{\mathrm{i}}$ values were, respectively, $7.24 \pm 0.02,7.25 \pm 0.02$, and $7.24 \pm 0.02(p=$ NS vs basal at all time points). 


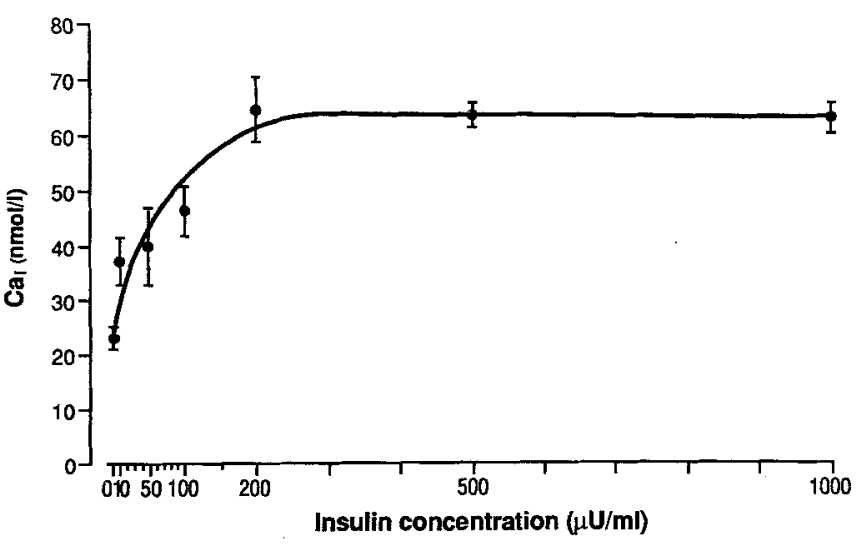

Fig.3. Dose response curve of the effect of insulin on erythrocyte intracellular free calcium, $\mathrm{Ca}_{\mathrm{i}}$

Insulin stimulated $\mathrm{Ca}_{\mathrm{i}}$ levels in all subjects, an effect which was dose dependent. When increasing doses of insulin were added to different aliquots of blood from the same subject, $\mathrm{Ca}_{\mathrm{i}}$ rose in a hyperbolic fashion, asymptotically approaching peak values at $200 \mu \mathrm{U} / \mathrm{ml}$, and plateauing thereafter, identical results being obtained at 500 and $1000 \mu \mathrm{U} / \mathrm{ml}$ concentrations. Conversely, even the lowest concentration of insulin tested, $10 \mu \mathrm{U} / \mathrm{ml}$, significantly $(p<0.05)$ elevated $\mathrm{Ca}_{\mathrm{i}}$ levels. At each dose, the $\mathrm{Ca}_{\mathrm{i}} \mathrm{re}-$ sponses were: basal, $22.9 \pm 2.1 \mathrm{nmol} / \mathrm{l} ; 10 \mu \mathrm{U} / \mathrm{ml}, 37.1 \pm$ $4.3 \mathrm{nmol} / \mathrm{l} ; 50 \mu \mathrm{U} / \mathrm{ml}, 39.8 \pm 7.1 \mathrm{nmol} / \mathrm{l} ; 100 \mu \mathrm{U} / \mathrm{ml}, 46.3 \pm$ $4.5 \mathrm{nmol} / \mathrm{l}$; and $200 \mu \mathrm{U} / \mathrm{ml}, 64.8 \pm 5.8 \mathrm{nmol} / 1$. Further increases in insulin $(500$ and $1000 \mu \mathrm{U} / \mathrm{ml})$ did not cause any further increase in $\mathrm{Ca}_{\mathrm{i}}$ (Fig.3).

\section{Discussion}

The clinical association of hypertension with obesity, insulin resistance, hyperinsulinaemia, with or without overt Type 2 diabetes, has long been appreciated, and a role for insulin itself in the hypertensive process has been postulated [1-8]. We have focussed on a role for altered cellular ion metabolism in mediating this association, and observed that the afore mentioned disorders in whole or in part, are characterized by increased cytosolic free calcium, and suppressed free magnesium and $\mathrm{pH}$ values $[9,17]$.

To investigate the extent to which the hyperinsulinaemia characterizing each of these clinical states could itself be responsible for these ionic alterations, we utilized ${ }^{19} \mathrm{~F}$ - and ${ }^{31} \mathrm{P}$-NMR spectroscopic techniques to study the direct in vitro effects of insulin on $\mathrm{Ca}_{\mathrm{i}}, \mathrm{Mg}_{\mathrm{i}}$, and $\mathrm{pH}_{\mathrm{i}}$ levels in human erythrocytes. We observed that at physiological concentrations insulin concurrently elevated $\mathrm{Ca}_{\mathrm{i}}$ and $\mathrm{Mg}_{\mathrm{i}}$ levels, but did not result in a significant change in $\mathrm{pH}_{\mathrm{i}}$. These results not only confirm previous reports [18], but suggest that hyperinsulinaemia per se cannot account for either the $\mathrm{Mg}_{\mathrm{i}}$ or $\mathrm{pH}_{\mathrm{i}}$ disturbances which we previously reported in hypertension and diabetes. However, our results demonstrate for the first time a functional role of insulin in the mature human erythrocyte, and suggest that insulin may participate in the regulation of erythrocyte ion homeostasis. Future studies of ions in the erythrocyte will therefore require a consideration of the insulinaemic status of the subject, and whether blood was obtained in the fasted or fed state.

Insulin directly elevated $\mathrm{Ca}_{\mathrm{i}}$ in the erythrocyte at all doses tested, from $10 \mu \mathrm{U} / \mathrm{ml}$ to $1000 \mu \mathrm{U} / \mathrm{ml}$, confirming a report in isolated adipocytes, where $\mathrm{Ca}_{\mathrm{i}}$ was measured using fluorescent probe techniques [19]. The mechanism by which insulin increases $\mathrm{Ca}_{\mathrm{i}}$ is still unknown, although its action to inhibit CaATPase [20,21], as well as to stimulate protein kinase $\mathrm{C}$ and diacylglycerol formation $[22,23]$ may be involved. The latter mechanism, dependent on $\mathrm{Ca}_{i}$ release from intracellular stores, cannot account for the results observed here in the erythrocyte.

The action of insulin to increase $\mathrm{Mg}_{\mathrm{i}}$ also confirms data obtained previously using different techniques, in which total intracellular magnesium content increased in response to insulin applied to erythrocytes [18] and uterine smooth muscle cells [24]. Possible mechanisms include its action on an ATPase-dependent Mg pump [25], as well as via an Na-stimulated $\mathrm{Mg}$ transport system recently described in human erythrocytes [26]. In the present study we were not able to detect any direct insulin effect on $\mathrm{pH}_{\mathrm{i}}$ in vitro, despite evidence that insulin stimulates $\mathrm{Na}^{+} / \mathrm{H}^{+}$ exchange in vitro [27], and that $\mathrm{pH}_{\mathrm{i}}$ rises following glucose loading in vivo [28]. Indeed, a reduction [29], no change [30], or an increase [31] in $\mathrm{pH}_{\mathrm{i}}$, have been observed with insulin, which may depend on the presence of other concurrent factors [22].

What are the possible clinical implications of these data? First, despite epidemiologic studies linking hyperinsulinaemia to elevated blood pressure $[1,3]$, insulin itself is a vasodilator, and may even induce hypotension in the absence of an adequate, compensatory rise in catecholamine activity [32]. Secondly, and in a parallel manner, the result of insulin action to increase both $\mathrm{Ca}_{\mathrm{i}}$ and $\mathrm{Mg}_{\mathrm{i}}$ concentrations may also appear antagonistic, these ions affecting blood pressure differently; the increase in $\mathrm{Ca}_{\mathrm{i}}$ increasing peripheral vasoconstriction and possibly elevating blood pressure, while an increase in $\mathrm{Mg}_{\mathrm{i}}$ having the opposite effect [33]. Thus, magnesium antagonizes calcium entry into vascular smooth muscle [34], competes for calcium binding on calmodulin [35], and may induce vasodilatation [36]. $\mathrm{Mg}_{\mathrm{i}}$ may also influence the intracellular content and disposition of calcium, decreased $\mathrm{Mg}_{\mathrm{i}}$ levels being associated with increased levels of $\mathrm{Ca}_{\mathrm{i}}$ in both essential hypertension and Type 2 diabetes [9]. If insulin itself contributes to the hypertensive process, then our data as well as those of others $[37,38]$ suggest the hypothesis that a dissociation of this normal, balanced cellular ionic action of insulin may occur, in which insulin-stimulated calcium accumulation predominates vis-à-vis its action to promote cellular magnesium uptake, the result being enhanced vasoconstriction, platelet aggregation, and other consequences of excess cellular calcium accumulation.

In summary, this study supports the hypothesis that insulin is an important modulator of intracellular divalent cation metabolism, independently of glucose transport. Further studies are needed to clarify whether altered cellular ionic responses to insulin are present in insulin-resistant states. Lastly, regardless of other implications, this study indicates that all future clinical studies of cellular ion 
metabolism should be performed in the fasting state, take into account circulating insulin levels, or both.

\section{References}

1. Modan M, Halkin H, Almay S et al. (1985) Hyperinsulinemia: a link between hypertension, obesity and glucose tolerance. J Clin Invest 75: 809-817

2. Ferrannini E, Buzzigoli G, Bonadonna R et al. (1987) Insulin resistance in essential hypertension. N Engl J Med 317: 350-357

3. Welborne TA, Wearne K (1979) Coronary heart disease incidence and cardiovascular mortality in Busselton with reference to glucose and insulin concentration. Diabetes Care 2: 154-160

4. Reaven GM, Hoffman BB (1987) A role for insulin in the aetiology and course of hypertension. Lancet 2: 435-437

5. DeFronzo RA, Cooke CR, Andres R, Fabona CR, Davis PJ (1975) The effect of insulin on renal handling of sodium, potassium, calcium and phosphate in man. J Clin Invest 55: 845-855

6. Rowe JW, Young BY, Minaker KL, Stevens AL, Pallata J, Landsberg L (1981) Effect of insulin and glucose infusion on the sympathetic nervous system activity in normal men. Diabetes 30 : 219-225

7. Rocchini AP, Moorehead C, De Remer S, Goodfriend TL, Ball DL (1990) Hyperinsulinemia and the aldosterone and pressor response to angiotensin II. Hypertension 15: 861-866

8. Stout RW, Bierman E, Ross R (1975) Effect of insulin on the proliferation of cultured primate arterial smooth cells. Circ Res 36 : 319-327

9. Resnick LM, Gupta RK, Bhargava KK, Gruenspan H, Alderman MH, Laragh JH (1991) Cellular ions in hypertension, diabetes, and obesity: a nuclear magnetic resonance spectroscopic study. Hypertension 17: 951-957

10. Resnick LM, Gupta RK, Laragh JH (1984) Intracellular free magnesium in erythrocyte of essential hypertension. Proc Natl Acad Sci USA 81: 6511-6515

11. Resnick LM, Roman MJ, Gupta RK, Laragh JH (1990) Intracellular cation determinants of left ventricular mass. Am J Hypert 3: $15 \mathrm{~A}$ (Abstract)

12. Resnick LM, Gupta RK, Gruenspan H, Alderman MH, Laragh JH (1990) Hypertension and peripheral insulin resistance: mediating role of intracellular free magnesium. Am J Hypertens 3: 373-379

13. Resnick LM, Barbagallo M, Gupta RK, Laragh JH (1991) How do insulin and glucose contribute to hypertension? - cellular ionic effects. J Am Soc Nephrol 2: 482 (Abstract)

14. Resnick LM, Gupta RK, Sosa RE, Corbett ML, Laragh JH (1987) Intracellular $\mathrm{pH}$ in human and experimental hypertension. Proc Natl Acad Sci USA 84: 7663-7667

15. Moon RB, Richards JH (1973) Determination of intracellular $\mathrm{pH}$ by ${ }^{31} \mathrm{P}$ magnetic resonance. J Biol Chem 248:7276-7278

16. Levy LA, Murphy E, London RE (1987) Synthesis and characterization of ${ }^{19} \mathrm{~F}$-NMR chelators for measurement of cytosolic free calcium. Am J Physiol 252: C441-C449

17. Resnick LM (1991) Calcium metabolism in hypertension and allied metabolic disorders. Diabetes Care 14: 505-520

18. Paolisso G, Sgambato S, Passariello B et al. (1986) Insulin induces opposite changes in plasma and erythrocyte magnesium concentration in normal man. Diabetologia 29: 644-647

19. Draznin B, Kao M, Sussman KE (1987) Insulin and glyburide increase cytosolic free calcium concentration in isolated rat adipocytes. Diabetes 36: 174-178

20. Perhshading HA, McDonald J (1979) Direct addition of insulin inhibits a high affinity $\mathrm{Ca}-\mathrm{ATP}$ ase in isolated adypocyte plasma membranes. Nature(Lond) 281: 495-497

21. Davis FB, Davis PJ, Nat G et al. (1985) The effect of in vivo glucose administration on human erythrocyte $\mathrm{Ca}$-ATPase activity and on enzyme responsiveness in vitro to thyroid hormone and calmodulin. Diabetes 34: 639-646

22. Molenaar WH, Tsien RY, van der Saag PT, Laat SW (1983) Na-H exchange and cytoplasmic $\mathrm{pH}$ in the action of growth factors in human fibroblasts. Nature (Lond) 304: 645-648

23. Hoffman JM, Ishizuka T, Farese RV (1991) Interrelated effects of insulin and glucose on diacylglycerol-protein kinase-C signalling in rat adipocytes and solei muscle in vitro and in vivo in diabetic rats. Endocrinology 128: 2937-2948

24. Lostroh AJ, Krahl ME (1973) Accumulation in vitro of magnesium and potassium in rat uterus: ion pump activity. Bioch Bioph Acta 291: 260-268

25. Lostroh AJ, Krahl ME (1974) Magnesium, a second messenger for insulin: ion translocation coupled to transport activity. Adv Enzyme Regulation 12: 73-81

26. Feray JC, Garay R (1986) An $\mathrm{Na}^{+}$-stimulated $\mathrm{Mg}^{2+}$-transport system in human red blood cells. Bioch Bioph Acta 856: 76-84

27. Pontremoli R, Rivera A, Canessa M (1991) Insulin and cytosolic free calcium modulate the human red cell $\mathrm{Na} / \mathrm{H}$ exchanger. Clin Res 39: 192A (Abstract)

28. Resnick LM, Gupta RK, Gruenspan H, Laragh JH (1988) Intracellular ion response to glucose tolerance: relation of hypertension, obesity, and insulin resistance. Circulation 78: II 570 (Abstract)

29. Taylor DJ, Coppack SW, Cadoux-Hudson TAD et al. (1991) Effect of insulin on intracellular $\mathrm{pH}$ and phosphate metabolism in human skeletal muscle in vivo. Clin Sci 81: 123-128

30. Meyer RA, Kushmerick MJ, Dillon PF, Brown TR (1983) Lack of insulin effect on intracellular pH in mammalian skeletal muscle. Fed Proc 42: 1248 (Abstract)

31. Klip A, Ramal T, Cragoe EJ Jr (1986) Insulin-induced cytoplasmic alkalinization and glucose transport in muscle cells. Am J Physiol 250: C720-C728

32. Mathias CJ, daCosta DF, Fosbraey P, Christensen NJ, Bannister $\mathrm{R}$ (1987) Hypotensive and sedative effect of insulin in autonomic nervous failure. Br Med J 295: 161-163

33. Resnick LM (1989) Hypertension, and abnormal glucose homeostasis: possible role of divalent cation metabolism. Am J Med 87 [Suppl 6A]: 17S-22S

34. Karaki H, Hatano K, Weiss GB (1983) Effect of magnesium on ${ }^{45} \mathrm{Ca}$ uptake and release at different sites in rabbit aortic smooth muscle. Pfluegers Arch 398:29-32

35. Tasi MD, Dragemberg T, Thulin E, Forsen S (1987) Is the binding of magnesium to calmodulin significant? An investigation by magnesium-25 nuclear magnetic resonance study. Biochemistry 26: $3635-3643$

36. Altura BM, Altura BT, Carella A, Gebrenwold A, Mukarawa T, Nishio A (1987) Mg-Ca interaction in contractility of vascular smooth muscle: $\mathrm{Mg}$ versus organic calcium channel blockers on myogenic tone and agonist-induced responsiveness of blood vessels. Can J Physiol Pharmacol 65: 729-745

37. Paolisso G, Passariello B, Sgambato S et al. (1987) Impaired insulin-mediated erythrocyte magnesium accumulation in essential hypertension. Clin Sci 73: 535-539

38. Paolisso G, Sgambato S, Giugliano D et al. (1988) Impaired insulin-induced erythrocyte magnesium accumulation is correlated to impaired insulin-mediated glucose disposal in type 2 (non-insulin-dependent) diabetic patients. Diabetologia 31:910 915

Received: 14 July 1992 and in revised form: 6 October 1992

Dr. L.M.Resnick

Division of Endocrinology and Hypertension

Wayne State U. Med School

Univ. Health Center - $4 \mathrm{H}$

4201 St.Antoine

Detroit, MI., 48201, USA 